\title{
History of the Foundation and the First Decade's Work of the British Empire Leprosy Relief Association.
}

\author{
Sir LEONARD ROGERS.
}

$7 \mathrm{HE}$ completion of the first decade of the work of the British Empire Leprosy Relief Association (BELRA for short) affords a fitting opportunity for recording a brief history of its foundation and progress.

\section{The Events that Led to the Formation of THE Association.}

Discovery of an improved treatment of leprosy.-It is not too much to say that a single decade before the foundation of the Association, in the latter part of 1923, the outlook for the unfortunate sufferer was little better than in the Middle Ages. The only prophylactic measure was compulsory segregation of all cases which was, in effect, a sentence of life-long imprisonment with no likelihood of recovery, in the vain hope that the disease might thus be stamped out in time. The innumerable remedies advised in its treatment bore witness to their small value, and none of them had ever sufficed to clear up the symptoms and remove the infectivity of any appreciable number of cases. This is shown in my Cameron Prize Lecture given before the University of Edinburgh in 1929*, which records with 88 references, the recent advances in treatment.

The most generally used of these methods was the old Indian remedy, chaulmoogra oil, which Ralph Hopkins of Lousiana showed to have some power of retarding the progress of the disease, but it was too nauseating to be curative. In the first decade of the present century the writer, working in Calcutta, had found gynocardic acid, the lower melting point fatty acids of chaulmoogra oil, to be less nauseating and more effective orally than the whole oil, and a medical colleague of his was cleared of a widespread leprosy rash by it. After demonstrating the great value of injections of emetine, the active principle of the ancient remedy ipecacuanha, he wrote in 1912 to a firm of manufacturing chemists, who had previously done valuable research in showing that chaulmoogra and hydnocarpus oils consisted mainly of chaulmoogric, hydnocarpic acids, and so-called gynocardic acid, to ask if they could prepare

* Edinburgh Medical Journal, January, 1930. 
soluble products of these fatty acids suitable for injection, but a reply in the negative was received.

In the meantime, Dr. Victor G. Heiser, the founder of the great Culion leprosy segregation settlement of the Philippines, had been using very painful intramuscular injections of chaulmoogra oil with beneficial results, apparently of a temporary nature, as Dr. Wade later could find no evidence of any of the patients having been discharged recovered. In the middle of 1915, while on a visit to Calcutta, Dr. Heiser urged Rogers to undertake further work on the subject, with the result that soluble gynocardate of soda was made. This was reported by Rogers in February, 1916, to be of greater value by injection than the fatty acid orally. Later in the same year, he showed that it could safely be given with still better results intravenously, and that it thus might produce reactions in the leprous lesions with actual breaking up of the causative acid fast bacilli in the human tissues. A year later, Rogers was able to record, with photos and coloured plates, a series of 26 cases with complete disappearance of all the leprous lesions in 50 per cent. of cases of not more than 3 years duration, and in 25 per cent. of those of 3 to 5 years duration before treatment. Thus the important principle was established, that the injection of soluble preparations of the active principles of chaulmoogra and hydnocarpates constituted an effective treatment more especially of early cases of leprosy.

Subsequent improvements in the technical application of this principle may be briefly mentioned. During his four and a half years' investigations in Calcutta Rogers showed that hydnocarpates were more effective than chaulmoogrates, and hydnocarpus wightiana oil from Western India was better than the chaulmoogra oil of Burma. After his return to England in 1920, he obtained a less irritating form of sodium hydnocarpate in the form of alepol, about half a million doses of which are being supplied yearly to British Possessions by BELRA. In the meantime in 1919 Hollmann and Dean, in Honolulu, after confirming the earlier work of Rogers, reported favourably on intramuscular injections of ethyl ester chaulmoogrates and hydnocarpates, which have since been used very extensively by American workers, with the addition of iodine, and by E. Muir and others, with the addition of creosote as an antiseptic, although this modification is much more expensive than alepol. In 1925, E. Muir, who has been working since 1920 as leprosy research worker in the Calcutta 
School of Tropical Medicine, founded by Rogers, established the value of a still simpler and cheaper modification in the form of fresh pure hydnocarpus wightiana oil with 4 per cent. creosote, which is most extensively used in India.

The leprosy problem in the British Empire.-Previous to the establishment of an improved treatment for the less advanced cases of leprosy, the problem of reducing materially the incidence of this justly dreaded disease, appeared to be so hopeless that it attracted little attention, and it was not until Muir and others sought out early cases for treatment that the magnitude of the problem hecame evident. Thus a survey of over $2 \frac{1}{2}$ million people in India has revealed $4 \frac{1}{2}$ times as many cases of leprosy as are returned in the census figures, mostly early ones, making a total of not less than 500,000 in India alone. In 1921, Rogers commenced a three years' study of the more important literature on leprosy during the previous half century on the distribution, epidemiology, infectivity and prophylaxis, which formed the basis of various papers and addresses, and a book on leprosy (published by John Wright and Sons, Bristol) in conjunction with Dr. E. Muir, who contributed the clinical and treatment sections. Among other things, these researches established a high incidence of leprosy in humid hot climates, with the highest rates per mille in tropical Africa, that the majority of infections occur in the first two decades of life, that 80 per cent. are contracted by living in the same house as a case of leprosy, but only 3 to 5 per cent. of those thus exposed develop leprosy, and that the incubation period averages two to three years and in 80 per cent. is under five years. He therefore advocated as the most rapid method of reducing leprosy incidence, the examination of the households and other contacts of known cases every few months for five to ten years, to enable the great majority of infections arising from them to be detected and cleared up by treatment in the early amenable stages. If nearly all these can be prevented from reaching an infective stage, within a single decade the sources of infection would be very greatly reduced by the infective cases present at the beginning of the decade either dying or passing into an uninfective nerve stage, for the more acute dermal cases are twenty times as infective as the chronic nerve ones. Recent trials of this plan in Naura Island and in the Sudan, described at the 1933 meeting of BELRA's General Committee, indicate that the nearer this ideal can be approached the more rapidly and economically will leprosy be reduced in any area to easily manageable proportions. 
The time had now come when it was essential to make the new knowledge known throughout the British Empire by means of an organized effort, and fortunately with the hour the men to carry it through were available.

\section{The Foundation of the British Empire Leprosy Relief Association.}

The writer had already raised at council meetings of the Mission to Lepers, which had for long provided financial support to various missionary bodies engaged in administering a large proportion of the leprosy asylums in India, the question as to whether they could extend their work to providing out-patient clinics for the treatment of early cases of leprosy, but this was not considered to be practicable. On March 29th, 1923. Mr. Frank Oldrieve, for long Secretary for India to the Mission to Lepers, came to ask the writer to speak at a public meeting of the Mission in Cambridge, and he also broached the question of forming a new association to inaugurate leprosy work throughout the Empire. As Mr. Oldrieve no longer felt fit for whole time work in India, the Mission to Lepers were willing to release him on the completion of his deputation work in November, 1923, and his organizing abilities and personality as a wholetime Secretary of the proposed association would ensure its success and provide just what the writer had no time to undertake, so the opportunity was too good to be lost. Sir Frank Carter, a philanthropic Calcutta friend, was next enlisted in the good cause, and he has ever since been Treasurer of the Association. The writer next obtained the sympathy and support of a number of prominent public men of great weight, including Lord Chelmsford, who rendered invaluable service as Chairman of the General Committee, Lord Ronaldshay, Governor of Bengal, Sir Edward Gait, formerly Governor of Bihar and Orissa, who has proved a tower of strength as Chairman of the Executive Committee, Sir Humphrey Rolleston and Sir John Rose Bradford, each of whom has been President of the Royal College of Physicians of London, and the latter has throughout been Chairman of the Medical Committee, and many members of the Association whose names appear on our general and medical Committees. It is most gratifying to the writer that he cannot recall a single refusal to his appeals for the support of so many very busy men.

A meeting of a number of influential supporters was held at the India Office on July 12th, 1923, with Lord 
Chelmsford in the chair, when the Association was inaugurated, and an Executive Committee, with Sir Edward Gait as Chairman, was constituted to complete the organization and to arrange for a public appeal to be made later at the Mansion House, permission for which had already been obtained. In September the writer drafted an appeal and a note on the medical policy, which were accepted by the Executive and Medical Committees, and a questionnaire on the incidence of leprosy and modes of prophylaxis in use was drawn up for circulation to all British Possessions. The Mansion House appeal had been fixed for December, but had to be postponed on account of an unexpected general election, to January 31st, 1924, when Lord Chelmsford, Lord Peel, Secretary for State for India, Sir Humphrey Rolleston, and the writer, spoke and asked for a considerable capital sum to enable the work of the Association to make a good start. By an unfortunate combination of adverse circumstances, including the recent subscription by the city of London of a quarter of a million pounds to the Japanese Earthquake Relief Fund, and the taking of 'office by the first Socialist Government, with fear of increased taxation, doubtless aided by the inexperience of the founders of our Association in the technique of appeals in Great Britain, this appeal brought in very little money and was most disappointing, so $\mathrm{Mr}$. Oldrieve and the writer had to set to work to raise funds by other means.

Formation of provincial branches of BELRA.-As we had failed to obtain any substantial help in our great Empire work from its wealthy capital city, we turned to the provinces with happier results. In January to June, 1924, Mr. Oldrieve organized meetings at which we both spoke at Rotary Clubs and in Municipal Offices, etc. in Bristol, Glasgow, Liverpool, Birmingham, Dublin, Manchester and Edinburgh. The writer had hoped to get the support of particular cities for leprosy work in some part of the Empire overseas with which they traded, such as Liverpool to finance work in West Africa, but owing to a slump in trade the appeal there failed. Active branches were, however, formed in Edinburgh, Glasgow and Bristol.

During 1928, after his return from his East African tour, Mr. Oldrieve organized further branches in Aberdeen, Dundee, Plymouth, Cheltenham and Rugby, and Sir Edward Gait has also spoken at a number of our branch meetings. Up to 1933 no less than $£ 13,400$, out of the total receipts of $£ 56,772$, has been received from our branches. 